\title{
The Recital Relationship between Share Prices of Indian Industries during the GST Implementation
}

\author{
Angelin Kiruba ${ }^{1}$ and S. Vasantha ${ }^{2}$ \\ ${ }^{1}$ Research Scholar, ${ }^{2}$ Professor \\ School of Management Studies, Vels Institute of Science, Technology \& Advanced Studies (VISTAS), Chennai, India \\ E-Mail: kirubasamraj@gmail.com, vasantha.sms@velsuniv.ac.in
}

\begin{abstract}
In India, earlier we pay various taxes i.e. Direct and Indirect taxes, which are felt as burden on people and due to these taxes, the corruption is increasing. To avoid this issue Indian Government is decided to have the changes in the Tax payment. So the decision what they have took is to have the unique tax percentage across the country.Before the GST introduced, there are different types of taxes has to be paid by the public as well as the people who do the business. GST is successfully implemented in various countries. GST tax will combine all the direct and indirect taxes paid by the individuals. This tax will help to increase the Gross Domestic Product GDP of the country. It is proven in the countries which are adopted the GST method in the Tax. And also the pain of paying multiple taxes for product or services will get reduce. This tax is the comprehensive tax of central and state government. This paper analyse the what kind of changes happened in the share market after the introduction of GST in India. It provide the variation of share price before and after the GST.
\end{abstract}

Keywords: GST, Stock Market, Impact Analysis

\section{INTRODUCTION}

Goods and Services Tax (GST) is an indirect tax which was introduced in India on 1 July 2017 and was applicable throughout India which replaced multiple cascading taxes levied by the central and state governments. It was introduced as The Constitution (One Hundred and First Amendment) Act 2017, following the passage of Constitution 122nd Amendment Act Bill. The GST is governed by a GST Council and its Chairman is the Finance Minister of India. Under GST, goods and services are taxed at the following rates, $0 \%, 5 \%, 12 \%, 18 \%$ and $28 \%$. There is a special rate of $0.25 \%$ on rough precious and semiprecious stones and $3 \%$ on gold. In addition a cess of $22 \%$ or other rates on top of $28 \%$ GST applies on few items like aerated drinks, luxury cars and tobacco products. GST replaced a slew of indirect taxes with a unified tax and is therefore set to dramatically reshape the country's 2 trillion dollar economy.

The GST expectation of whole taxation system available in the tax structure is, GST has to create the easy way of market. The economic experts believing GST will increase the growth of the country and it will create the common market among the corporate sector and in the Indian Economy.
The pre-implemented GST discussion about the proposed GST structure is likely to succeed only if the country has a strong IT network. It is a well-known fact that India is still in the budding state as far as internet connectivity is concerned. Moreover, the proposed regime seems to ignore the emerging sector of e-commerce. E-commerce does not leave signs of the transaction outside the internet and has anonymity associated with it. As a result, it becomes almost impossible to track the business transaction taking place through internet which can be business to business, business to customer or customer to customer. Again, there appears to be no clarity as to whether a product should be considered a service or a product under the concept of Ecommerce. New techniques can be developed to track such transactions but until such technologies become readily accessible, generation of tax revenue from this sector would continue to be uncertain and much below the expectation. Again E-commerce has been insulated against taxation under custom duty moratorium on electronic transmissions by the WTO Bali Ministerial Conference held in 2014.

\section{REVIEW OF LITERATURE}

Priyanshu Sharma and Dr.Manoj Sain (2017), as per their research on impact on Indian stock exchanges of various stock sectors, they analysed to find out the uncertainties of stock price due to GST implementation. Banking, finance and loan sector has been taken for their research. They validated the share price of these sectors before and after implementation of GST. Based on their research they found it was given the positive impact on these sectors even though it was the fear when the time of implementation of GST.

Dr. Alice Mani, Abhishek Singh and Chinmayi C.V(2017) analysed on the impact of GST on seven selected sectors of BSE and for that they took stock prices of automobile, banking, FMCG, healthcare and manufacturing sectors. They have used the coefficient, t-statistics, regression and F-statistics to find out the volatility in stock prices during implementation period. From their research they concluded that except automobile and banking sector there is no significant effect in other sectors which they taken for their analysis.

Lakshmi. B and Rebecca J Alex (2017), examined on the effect of GST rate announcement on sectorial indices of 
NSE of India. The main objective of their study is to find out whether the GST implementation is created the semi or strong relationship. OLS, GARCH and TGARCH has been used for their research. Daily closing price of Automobile ,Banking, Financial services, FMCG, IT, Media, Metal, Pharma, PSU Bank, PVT Bank, Realty, Energy, MNC and Infra has been used. PSU Bank, They concluded that realty sector and Pharmaceutical has been created the more significant difference when comparing with the other nine sector they have used for their research.

Glyn Wittwer and Kym Anderson (2002), as per their research on impact of GST introduction created the effect on wine industry. Before the GST implementation, in Australia the wine tax rate is little higher than the GST tax. Based on their research they have concluded that since the tax rate has been reduced the rate of the wine also got reduced which is created the significant positive result in the wine industry.

Ayesha Jaiswal (2017), GST will be beneficial for the stock market as it will send a positive message to the foreign investor. India will represent as a better policy maker in front of the foreign market, and then it will lead foreign investor to make an investment in the Indian stock market. It will boost our economy as well as the reputation of the Indian country.

Dr. Yogesh Kailashchandra Agrawal (2017), as per his research on goods and services tax and its impact of Indian economy, he examined the various sector based on the various research article done by the researchers and different books and newspapers collection. The objective of his study is to find out the highlight of impact of GST and to explain the working mechanism of GST. He find that it will take long time to get the good amount of revenue for the people who are in the business.

After implementation of GST in Malaysis (Mar 2015), Chief executive officer Datuk Tajuddin Atan said to the Bursa Malaysia's annual general meeting, "The GST won't be charged on the value of the whole securities transactions but only on the fees related to the transactions such as brokerage and clearing fees.

It has deeply impacted the poor households in Pakistan in a negative way especially during the period (1990-2001). Therefore, India being similar to Pakistan regarding economy and culture may have a similar impact. According to research, taxation of items like sugar, fuel, and ghee is impacting the poor greatly (Refaqat \& Mohsin, 2005).

Angelin Kiruba, Dr. S. Vasantha(2018) ICIRST-18, the same industries were used for their research and identified the demonetisation impact of these industries. The research finding was during short period of timeline alone, the share values fluctuated due to demonetisation. But all the industries again back to the normal stage within the three months of timeline.

\section{A. Event Study}

Event study is the empirical analysis done on the shares to validate the share prices variations because of some significant event happened in the particular period. For example, Bankruptcy and recession. There are lot of methods followed to analyse the variations of share prices due to the particular event.

The methodology followed in the event study will provide historical information of the firm's stock. The abnormal return, average return and normal vs average return are the few methodology used for calculating the stock price during the event period. It is the statistical representation of the share price during the event period.

\section{OBJECTIVE OF THE STUDY}

This study aims to evaluate relationship between the before and after implementation of GST and its influence in the share market of selected Indian Industries. The results drawn will be used to make predictions with regards to changes in key variable (Share Price) after GST gets introduced in India.

\section{METHODS AND ANALYSIS OF DATA}

According to Mitchell, Netter (1994) and MacKinlay (1997), event study is done "using financial market data" to "measure the impact of a specific event on the value of a firm". The result which they got from their analysis is the changes of stock prices are happening only in the short period. And also they concluded that comparing with long time analysis, short period is reliable in the share market. Hence considering the same, short period horizon is used to find out the variation in the event.

This study is to analyse the impact on stock market which includes before GST, event window is referred as GST month and post event window is referred to as post GST situations. The share values has been taken from the April 2017 to December 2017 which is covered the pre and post period of the GST.

1. To investigate the impact of the share prices, the hypothesis test has been used as follows.

Ho: There is no changes in the stock before the event window.

$\mathrm{H} 1$ : There is a changes in the stock after the event window. 2. ANOVA analysis has been carried out in the study to find out an impact on stock returns during the period.

3. Multiple R: This is the correlation coefficient. It tells you how strong the linear relationship is. For example, a value of 1 means a perfect positive relationship and a value of zero means no relationship at all. It is the square root of $r$ squared.

4. $R$ squared. This is $\mathrm{r} 2$, the Coefficient of Determination. It tells you how many points fall on the regression line. for example, $80 \%$ means that $80 \%$ of the variation of $y$-values around the mean are explained by the x-values. In other words, $80 \%$ of the values fit the model. 
5. Adjusted $R$ square. The adjusted R-square adjusts for the number of terms in a model. It has to be used for more than one $\mathrm{x}$ variable.

6. Standard Error of the regression: An estimate of the standard deviation of the error $\mu$. This is not the same as the standard error in descriptive statistics. The standard error of the regression is the precision that the regression coefficient is measured; if the coefficient is large compared to the standard error, then the coefficient is probably different from 0 .

7. Observations. Number of observations in the sample.

\section{RESULTS}

TABLE I TRANSPORT AND LOGISTICS INDUSTRY

\begin{tabular}{|l|r|r|r|r|r|}
\hline Regression Statistics & \multicolumn{1}{|l|}{ Interglobe } & Container Corp & Jet airways & SpiceJet & Aegis logistics \\
\hline Multiple R & 0.19 & 0.64 & 0.21 & 0.08 & 0.22 \\
\hline R Square & 0.03 & 0.41 & 0.04 & 0 & 0.05 \\
\hline Adjusted R Square & -0.08 & 0.28 & -0.08 & -0.11 & -0.07 \\
\hline Standard Error & 26.17 & 14.19 & 14.26 & 2.54 & 2.57 \\
\hline Observations & 9 & 9 & 9 & 9 & 9 \\
\hline
\end{tabular}

From the table 1 analysis, (Given Regression line $=80 \%$ ), all companies $\mathrm{Y}$ values of share has not been fit in the event window of GST. Since the mean values are not fit in the event window, it means that there is no significant changes happened in the transport and logistics industries due to the GST.

\section{Hypothesis:}

H0: $(\mu 1=\mu 2=\mu 3)$ Mean return are equal there is no changes in the stock values.

H1: Mean returns are not equal. There is a change in the share values after the demonetisation.

From the Table 2 analysis, Given Sig.> 0.05, except Container Corp all other industries values are greater than the 0.05 or equal to 0.05 . It means that, in Container Corp industry after the GST the share return has been changed. All other industries, that is Interglobe, Spice Jet, Jet Airways, Aegis Logistics shares values has not been changed before, after and during the GST in the Transport and Logistics sector.

TABLE II TRANSPORT AND LOGISTICS INDUSTRY

\begin{tabular}{|l|r|r|}
\hline \multicolumn{3}{|c|}{ ANOVA } \\
\hline Companies & $F$ & Significance $F$ \\
\hline Interglobe & 0.31 & 0.59 \\
\hline Container Corp & 5.62 & 0.04 \\
\hline Jet airways & 0.37 & 0.56 \\
\hline SpiceJet & 0.05 & 0.81 \\
\hline Aegis logistics & 0.43 & 0.52 \\
\hline
\end{tabular}

From the table- 3 analysis, (Given Regression line $=80 \%$ ), all companies $\mathrm{Y}$ values of share has not been fit in the event window of GST. Since the mean values are not fit in the event window, it means that there is no significant, changes happened in the Hotel industries due to the GST.

TABLE III HOTEL INDUSTRY

\begin{tabular}{|l|r|r|r|r|r|}
\hline Regression Statistics & Hotel-ElH & India tourism D & Indian Hotels & Leela & Mahindra Holi \\
\hline Multiple R & 0.34 & 0.26 & 0.01 & 0.52 & 0.19 \\
\hline R Square & 0.11 & 0.06 & 0 & 0.27 & 0.03 \\
\hline Adjusted R Square & 0 & -0.07 & -0.14 & 0.13 & -0.1 \\
\hline Standard Error & 9.73 & 15.24 & 2.67 & 0.66 & 6.76 \\
\hline Observations & 9 & 8 & 8 & 8 & 8 \\
\hline
\end{tabular}

TABLE IV HOTEL INDUSTRY

\begin{tabular}{|l|r|r|}
\hline \multicolumn{3}{|c|}{ ANOVA } \\
\hline Companies & F & Significance $F$ \\
\hline Hotel-ElH & 1.08 & 0.33 \\
\hline India tourism D & 0.51 & 0.49 \\
\hline Indian Hotels & 0 & 0.97 \\
\hline Leela & 2.7 & 0.15 \\
\hline Mahindra Holiday & 0.28 & 0.61 \\
\hline
\end{tabular}

From the table-4 analysis, Given Sig.> 0.05, Hotel Leela has the slight changes in the share values during the GST period. However it is also greater than the significance difference of 0.05 . It means that, there is no difference in the share values of Hotel industries due to GST. Even though it was created assumption of giving the significant changes in the Hotel industries during the before launch of GST, based on this analysis we could not find any changes in the shares. 
TABLE V PERSONAL CARE

\begin{tabular}{|c|c|c|c|c|c|}
\hline Regression Statistics & Dabur & HUL & Colgate & Godrej consume & Marico \\
\hline Multiple R & 0.13 & 0.28 & 0.07 & 0.11 & 0.02 \\
\hline R Square & 0.01 & 0.08 & 0 & 0.01 & 0 \\
\hline Adjusted R Square & -0.12 & -0.06 & -0.13 & -0.12 & -0.14 \\
\hline Standard Error & 5.84 & 17.21 & 14.16 & 33.11 & 4.72 \\
\hline Observations & 8 & 8 & 8 & 8 & 8 \\
\hline
\end{tabular}

From the table- 5 analysis, (Given Regression line $=80 \%$ ), all companies $\mathrm{Y}$ values of share has not been fit in the event window of GST. Since the mean values are not fit in the event window, it means that there is no significant changes happened in the Personal Care industries due to the GST. Since all the Adjusted R Square is less than zero in all industries of personal care, it means that the performance of the share values given the positive impact during the introduction GST.

From the table-6 analysis, Given Sig.> 0.05, all industries values are greater than the 0.05 or equal to 0.05 .It means that, Colgate, Marico, Dabur, HUL and Godrej Consumer companies are after the GST the share return has not been changed. It means that GST is not creating any difference in the share values of personal care industries.

TABLE VI PERSONAL CARE
\begin{tabular}{|l|r|r|}
\hline \multicolumn{3}{|c|}{ ANOVA } \\
\hline Companies & F & Significance $F$ \\
\hline Dabur & 0.12 & 0.73 \\
\hline HUL & 0.63 & 0.45 \\
\hline Colgate & 0.04 & 0.84 \\
\hline Godrej consumer & 0.09 & 0.77 \\
\hline Marico & 0 & 0.95 \\
\hline
\end{tabular}

TABLE VII FOOD PROCESSING

\begin{tabular}{|l|r|r|r|r|r|}
\hline Regression Statistics & Britannia & GlaxoSmith Con & Hatsun Agro & Kwality & Nestle \\
\hline Multiple R & 0.03 & 0.26 & 0.51 & 0.51 & 0.11 \\
\hline R Square & 0 & 0.06 & 0.26 & 0.26 & 0.01 \\
\hline Adjusted R Square & -0.14 & -0.07 & 0.12 & 0.11 & -0.13 \\
\hline Standard Error & 33.26 & 70.32 & 11.8 & 3.66 & 57.75 \\
\hline Observations & 8 & 8 & 8 & 8 & 8 \\
\hline
\end{tabular}

From the table-7 analysis, (Given Regression line $=80 \%$ ), all companies $\mathrm{Y}$ values of share has not been fit in the event window of GST. Since the mean values are not fit in the event window, it means that there is no significant changes happened in the Food Processing industries due to the GST. Since all the Adjusted R Square is less than zero in all industries of Food Processing, it means that the performance of the share values given the positive impact during the introduction GST.

From the table-8 analysis, Given Sig.> 0.05, that is Britannia, Glaxosmith Con, Nestle, Hatsun Agro and Kwality share values has not been changed before, after and during the GST in the Food Processing sector. From the above table we are able to see all the companies share values are greater than the 0.05 . And also we may able to see the same kind of impact happened in the Hatsun Agro and Kwality companies share values during this segment.

\begin{tabular}{|l|r|r|}
\hline \multicolumn{3}{|c|}{ ANOVA } \\
\begin{tabular}{|l|r|r|}
\hline \multicolumn{3}{|c|}{ TABLE VIII FOOD ProCESSING } \\
\hline Companies & \multicolumn{1}{|c|}{ Significance $F$} \\
\hline Britannia & 0 & 0.92 \\
\hline GlaxoSmith Con & 0.52 & 0.49 \\
\hline Hatsun Agro & 2.53 & 0.16 \\
\hline Kwality & 2.47 & 0.16 \\
\hline Nestle & 0.08 & 0.77 \\
\hline
\end{tabular}
\end{tabular}

TABLE IX DOMEstic APPLIANCE

\begin{tabular}{|l|r|r|r|r|r|r|}
\hline Regression Statistics & Bajaj Electric & Butterfly & & Hawkins Coo & TTK Prestige & Viaan Ind \\
\hline Multiple R & 0.27 & 0.46 & 0.45 & 0.16 & 0.34 \\
\hline R Square & 0.07 & 0.21 & 0.2 & 0.02 & 0.12 \\
\hline Adjusted R Square & -0.06 & 0.07 & 0.06 & -0.11 & -0.02 \\
\hline Standard Error & 7.59 & 18.84 & 50.15 & 93.92 & 0.77 \\
\hline Observations & 8 & 8 & 8 & 8 & 8 \\
\hline
\end{tabular}


From the table- 9 analysis, (Given Regression line=80\%), except TTK Prestige share values, all other companies Y values of share has not been fit in the event window of GST. Since the mean values are not fit in the event window, it means that there is no significant changes happened in the Domestic Appliance industries due to the GST. Since all the Adjusted R Square is less than zero in all industries of Domestic Appliance, it means that the performance of the share values given the positive impact during the introduction GST.

TABLe X Domestic ApPliance

\begin{tabular}{|l|r|r|}
\hline \multicolumn{3}{|c|}{ ANOVA } \\
\hline Companies & $F$ & Significance $F$ \\
\hline Bajaj Electric & 0.55 & 0.48 \\
\hline Butterfly & 1.92 & 0.21 \\
\hline Hawkins Cooker & 1.82 & 0.22 \\
\hline TTK Prestige & 0.19 & 0.67 \\
\hline Viaan Ind & 0.96 & 0.36 \\
\hline
\end{tabular}

From the table-10 analysis, Given Sig.> 0.05, all the companies shares which is taken for calculations are not shown any difference due to the GST implementation. The companies significant value is greater than the 0.05 . It means that, selected industries of Bajaj Electric , Butterfly, Hawkins Cooker, TTK Prestige and Viaan Ind performed at the same level before, after and during the GST implementation period.

\section{FURTHER SCOPE OF RESEARCH}

While paper factually shows the impact of GST on various companies, there is some scope available to research related topic. A related area of the research could be a comparative study of the impact of GST on other industries.

\section{DISCUSSION}

As per the "The economic Times" release on Aug 11,2017, author Bipin Sapra clearly stated in initial phases GST is really expensive in initial period and there are people who is benefited and the losers during this time. However after his 40 days of analysis he concluded that GST transition is smooth.

And also in Money Control website, according to Nikhil Kamath, the effect of GST is more in the retail sector when comparing with the share market influence of GST. The same effect we can see on this article also. Not all the share values are created the major impact due to GST. But we could see the share price fluctuations in the consumable product of Personal Care, food processing and domestic appliances.

In this study, we analysed that any share values fluctuation happened on this selected five industries. From the analysis of Transport and logistics, there are no changes in share values during the pre and post implementation of GST period. Among the five companies from the transport and logistics, except Container Corp all the companies shares were not shown any differences in the share values. A $\mathrm{K}$ Prabhakar, head of research at IDBI Capital explains, after implementation GST, the impact in the financial performance will not give the immediate effect. The goods and services movement may get change. There may be some changes in the Tax after the introduction. All these facts may give the variation in the logistics industry. The same effect we can see based on the analysis we have taken in this paper. Grand Thornton tax and advisory firm, based on their survey they concluded that GST created has given the favourable situation on business and the hotel industries.

On analysing the Hotel industry effect on GST, during the introduction stage of GST consumer of every product worried on the GST payment which created the assumption of that will play the major role in such industry. But based on this study we can say in this segment among the selected five hotels, there is no variation happened during this period. All the companies shares were given the narrow performance. Only the small scale industries has been affected during this period.

GST is a landmark reform, which will bring in a lot of ease in doing business, and will be hugely beneficial for the country. As a result, of the reduction in the tax rates, we have immediately passed on the benefits to our consumers. The revision in GST rates is a welcome move and we feel it will help boost consumer and business sentiments," Malik said.

In the Personal Care area, the share values of the all the industries are created the casual effect. There is no changes in the share value. When considering the share values return, Colgate, Marico, Dabur, HUL and Godrej share's returns are not changed during this period which clearly states the same impact like other industries of Hotel and Logistics.

In the Food Processing segment, based on this study we can see the share value changes as well the share value's return changes during the event period. And also when comparing with above industries, this shows the difference in the share price. But all other above mentioned industries are not shown this difference. In the food processing also, not all the selected companies shows the variation in the share value return. All the companies share returns are same like early days.

The fifth industry we used for our analysis is Domestic Appliances. In this industry the impact of GST is shows the difference in the share values. Even though this industries share values are impacted by the GST, there is no significant difference in the share value return. All other companies of "Bajaj Electric,Butterfly,TTK Prestige, Hawkins Cooker and Viaan Ind" share value return has not been changed before, after and during the GST in the Domestic Appliance sector. As per Gupta thoughts to IANS, when the GST rate is getting reduced it will help to increase 
the sales and the goods will be more affordable. Based on this wording, we may get some changes on these industries when the GST is getting reduced.

\section{CONCLUSION}

The study ascertained the impact of GST in India on sectoral indices of BSE. Data from April 2017 to Dec 2017 has been used to validate the changes of share values during the GST announcement. Totally five sectors has been taken with companies share values of each sectors has been validated to find out the impact of GST. The hypothesis test at significance level of 0.05 has given some interesting conclusion. In all the five industries at least one company from the sample taken has been affected due to GST, this was the strong thought we had before we complete our analysis. Even though the introduction of GST created major impact of the day to today life of the people who is living in India, the share values are not affected due to the GST. But we could say the utility product shares values like personal care and domestic appliances are faced more differences when comparing with other sector. But this changes are not affected any of the shareholders mind set to reconsider the purchase or sell the shares. All the selected companies share values are performed as usual like normal days. We can conclude that in the share market of India, GST is not introduced any historical changes.

\section{REFERENCES}

[1] Angelin Kiruba \& Vasantha, S., (2018). "Impact of Demonetization on Stocks Market", in Indian Industries International Journal of Pure and Applied Mathematics. 118(5), 99-115. ISSN: 1311-8080.
[2] Anushya, \& Karam, P. N., (2014). "Indian Indirect Tax Systems' Reforms and Goods and Services Tax". Advancement In Management, 9-14.

[3] Bansal, A. (2010). "The Indian GST is moving towards the best realworld model of the tax". International Journal of Management Prudence, 1(2), 65-70.

[4] Belle, M. I., \& Freudenber, B., (2015). Calm waters: GST and cash flow stability for small businesses in Australia. eJournal of Tax Research, 13(2), 492-532.

[5] Mehra, P., (2015) Modi govt.'s model for GST may not result in significant growth push. The Hindu.

[6] Sehrawat, M., Dhanda, U., (2015), "GST in India: A key tax reform", "International journal of research granthaalayah", 3(12).

[7] Kumar, N., (2014). "Goods and service tax in India-A way forward", "Global Journals of multidisciplinary studies", 3(6).

[8] Patrick, M., (2015). Goods and Service Tax: Push for Growth. Centre for Public Policy Research (CPPR).

[9] Pinki, SupriyaKamna, RichaVerma (2014), "Good and Service Tax: Panacea For Indirect Tax System In India (2014), Tactful Management Research Journal, 2(10), July

[10] Purohit, M. C., (2010). "Issues in the Introduction of Goods and Services Tax". Economic and Political weekely, 45(5), 12-15.

[11] Chaurasia, P., Singh, S., and Kumar Sen, P., (2016), "Role of Goods and Service Tax in the growth of Indianeconomy", International journal of science technology and management, 5(2).

[12] Rao, G. (2009, JUL 18). Feasibility of Introducing GST in April 2010. Economic and Political weekely, 44(29), 1-13.

[13] Rao, G. (2009, December). Goods and Services Tax: Some Progress towards Clarity. Economic and Political Weekly, 44(51), 8-11.

[14] Rao, K. (2010, NOVEMBER-DECEMBER). Goods and Services Tax: The 13th Finance Commission and the Way Forward. Economic and Political Weekly, 45(48), 71-77.

[15] Refaqat, S., \& Mohsin, H. M. (2005, December). Redistributive Impact of GST Tax Reform: Pakistan, 1990-2001. The Pakistan Development Review, 44(4), 841-862.

[16] S., B. C., \& Math, R. B. (2014, Jan-Jun). Globalization and Tax reforms in India: Evidence from corporate sector. IPE Journal of Management, 4(1), 68-82.

[17] Vasanthagopal, R. D. (2011, April). GST in India: A Big Leap in the Indirect Taxation System. International Journal of Trade, Economics and Finance, 2(2), 144-146. 